\title{
IGF2 and IGF1R identified as novel tip cell genes in primary microvascular endothelial cell monolayers
}

\author{
Marchien G. Dallinga ${ }^{1} \cdot$ Bahar Yetkin-Arik ${ }^{1} \cdot$ Richelle P. Kayser $^{1} \cdot$ Ilse M. C. Vogels ${ }^{1} \cdot$ Patrycja Nowak-Sliwinska $^{2}$. \\ Arjan W. Griffioen ${ }^{3} \cdot$ Cornelis J. F. van Noorden ${ }^{1,4} \cdot$ Ingeborg Klaassen $^{1,6} \cdot$ Reinier O. Schlingemann $n^{1,5}$
}

Received: 12 March 2018 / Accepted: 18 June 2018 / Published online: 27 June 2018

(c) The Author(s) 2018

\begin{abstract}
Tip cells, the leading cells of angiogenic sprouts, were identified in cultures of human umbilical vein endothelial cells (HUVECs) by using CD34 as a marker. Here, we show that tip cells are also present in primary human microvascular endothelial cells (hMVECs), a more relevant endothelial cell type for angiogenesis. By means of flow cytometry, immunocytochemistry, and qPCR, it is shown that endothelial cell cultures contain a dynamic population of CD34 ${ }^{+}$cells with many hallmarks of tip cells, including filopodia-like extensions, elevated mRNA levels of known tip cell genes, and responsiveness to stimulation with VEGF and inhibition by DLL4. Furthermore, we demonstrate that our in vitro tip cell model can be exploited to investigate cellular and molecular mechanisms in tip cells and to discover novel targets for anti-angiogenesis therapy in patients. Small interfering RNA (siRNA) was used to knockdown gene expression of the known tip cell genes angiopoietin 2 (ANGPT2) and tyrosine kinase with immunoglobulin-like and EGF-like domains 1 (TIE1), which resulted in similar effects on tip cells and sprouting as compared to inhibition of tip cells in vivo. Finally, we identified two novel tip cell-specific genes in $\mathrm{CD} 34^{+}$tip cells in vitro: insulin-like growth factor 2 (IGF2) and IGF-1-receptor (IGF1R). Knockdown of these genes resulted in a significant decrease in the fraction of tip cells and in the extent of sprouting in vitro and in vivo. In conclusion, this study shows that by using our in vitro tip cell model, two novel essential tip cells genes are identified.
\end{abstract}

Keywords Angiogenesis · Tip cells $\cdot$ CD34 $\cdot$ IGF2 $\cdot$ Endothelial cells $\cdot$ Cultured cells $\cdot$ Endothelial growth factors

\section{Introduction}

New blood vessel sprouting is led by tip cells, a transdifferentiated phenotype of endothelial cells induced by pro-angiogenic factors including vascular endothelial growth factor

Electronic supplementary material The online version of this article (https://doi.org/10.1007/s10456-018-9627-4) contains supplementary material, which is available to authorized users.

Ingeborg Klaassen

i.klaassen@amc.uva.nl

1 Ocular Angiogenesis Group, Departments of Ophthalmology and Medical Biology, Amsterdam University Medical

Centers, Academic Medical Center, Amsterdam, The Netherlands

2 School of Pharmaceutical Sciences, University of Geneva, Geneva, Switzerland

3 Angiogenesis Laboratory, Department of Medical Oncology, Amsterdam University Medical Centers, VU University Medical Center, Amsterdam, The Netherlands
(VEGF) [1, 2]. In vivo, the tip cell phenotype is characterized by extension of filopodia, enhanced migratory propensity, and mitotic quiescence $[1,3]$. Tip cells differ in various aspects from the more proximal, proliferating stalk cells and the maturing phalanx cells [2], and express a distinct set of genes $[4,5]$. Until recently, progress in research on tip cells has been slow because of the need to use laboratory animals, as an in vitro model of tip cells was lacking. However, we

4 Department of Genetic Toxicology and Cancer Biology, National Institute of Biology, Ljubljana, Slovenia

5 Department of Ophthalmology, University of Lausanne, Jules-Gonin Eye Hospital, Fondation Asile des Aveugles, Lausanne, Switzerland

6 Ocular Angiogenesis Group, Department of Medical Biology, Amsterdam University Medical Centers, Academic Medical Center, Meibergdreef 15, Room L3-154, 1105 AZ Amsterdam, The Netherlands 
have identified tip cells in monolayer human umbilical vein endothelial cell (HUVEC) cultures employing CD34 as a marker [6]. In vivo, CD34 is expressed throughout the body at the luminal side of endothelial cells of small blood vessels and umbilical veins and on filopodia of tip cells [7], but we have shown that in monolayers of HUVECs that have been passaged at least three times, approximately $10 \%$ of the cells express high levels of CD34. Moreover, these CD34-positive HUVECs have a distinct phenotype, with striking similarities when compared to tip cells in vivo, including CD34 ${ }^{+}$ filopodia-like extensions, mitotic quiescence, and expression of tip cell specific genes $[6,8]$.

As validation of our in vitro model for tip cells, we investigated first whether $\mathrm{CD} 34^{+}$tip cells are also present in monolayer cultures of primary human microvascular endothelial cells (hMVECs), as angiogenesis in vivo is initiated in microvessels [9]. In addition, we studied the effects on $\mathrm{CD} 34^{+}$tip cells after silencing of two known tip cell genes, the growth factor angiopoietin-2 (ANGPT2) and the receptor tyrosine kinase with immunoglobulin-like and EGF-like domains 1 (TIE1), both of which were shown by us previously to have higher mRNA expression levels in CD34 ${ }^{+}$tip cells [6]. ANGPT2 is involved in angiogenesis and interacts with the actin cytoskeleton to induce migration [10]. Silencing of ANGPT2 in mouse models of angiogenesis results in the absence of tip cells at the front of new vessel sprouts in mouse retinas [11]. TIE1 is an orphan receptor, which is expressed on tip cells and a subset of stalk cells, and which is involved in survival signaling in stalk cells [12].

Then, we explored the role in angiogenesis of two novel tip cell genes identified by us on the basis of differential expression in microarrays of CD $34^{+}$and CD $34^{-}$HUVECs, insulin-like growth factor 2 (IGF2), and insulin-like growth factor-1 receptor (IGF1R) (6). Both genes belong to the IGF family of growth factors, which consists of the ligands IGF1 and IGF2, the receptors IGF1R, IGF2R, and insulin receptor (INSR), and at least 7 IGF binding proteins (IGFBPs). IGF2 binds to and signals through IGF1R and the other IGF receptors. In earlier studies, knockdown of IGF2 and IGF1R inhibited angiogenesis in developing mouse retina and in zebrafish [13-15], but a specific role of these proteins in tip cells has not yet been reported. Here, we used our tip cell model to further characterize the role in angiogenesis of these novel tip cell genes.

\section{Materials and methods}

\section{Cell cultures}

Primary HUVECs were isolated from umbilical cords (obtained from the Department of Gynecology, Academic Medical Center, Amsterdam, The Netherlands), as described earlier [16], and grown in M199 basal medium (Gibco, Grand Island, NY, USA) supplemented with 10\% heat inactivated human serum (obtained from the Department of Oncology, Academic Medical Center, Amsterdam, The Netherlands), $10 \%$ fetal bovine serum (Gibco), and $1 \%$ penicillin-streptomycin-glutamine (Gibco). HUVEC cultures were incubated with antibodies directed against CD31/PECAM-1 (1:100; eBioscience, Vienna, Austria) to check the purity of the endothelial cells. HMVECs, a kind gift of Dr. P. Koolwijk (VU University Medical Center, Amsterdam, The Netherlands), were cultured with 50\% HUVEC medium and 50\% EBM-2 medium (Lonza, Basel, Switzerland) and cells were characterized as previously described [17]. HUVECs and hMVECs were cultured in $2 \%$ gelatin-coated T75 culture flasks (Millipore, Billerica, MA, USA) at $37{ }^{\circ} \mathrm{C}$ and $5 \% \mathrm{CO}_{2}$. Experiments were performed with confluent HUVECs at passage 3 and hMVECs at passage $9-10$ of at least 3 different donors. Subjects gave informed consent for the use of tissues or serum, and samples were stored anonymously. Cells were treated with recombinant human VEGF-A (R\&D Systems, Minneapolis, MN, USA), IGF2 (ProSpec, Rehovot, Israel), bFGF (Sanquin, Amsterdam, The Netherlands), or DLL4 (R\&D Systems) as indicated.

\section{Immunocytochemistry}

Cells were cultured on gelatin-coated coverslips (Thermo Scientific, South Logan, UT, USA) for $72 \mathrm{~h}$ when treated with siRNA or until confluent for spheroids and sorting experiments. Cells were fixed in freshly-made $4 \%$ paraformaldehyde in phosphate-buffered saline (PBS, Lonza) for $15 \mathrm{~min}$ at room temp, and then blocked in PBS containing 10\% bovine serum albumin (BSA; Sigma-Aldrich, St. Louis, MO, USA) and 0.5\% Triton X-100 (Sigma) for $1 \mathrm{~h}$ at room temperature. Next, cells were incubated with a primary antibody against CD34 (diluted 1:100, clone MD34.2; Sanquin) for $2 \mathrm{~h}$ and a secondary anti-mouse Alexa 488 antibody (Life Technologies, Carlsbad, CA, USA) and phalloidin (Life Technologies) to stain for F-actin for $1 \mathrm{~h}$.

\section{DLL4 coating}

Culture flasks were coated according to Harrington et al. [16] using $0.2 \%$ gelatin in PBS, with $1 \mu \mathrm{g} / \mathrm{mL}$ of either recombinant human DLL4 (R\&D systems) or BSA for $24 \mathrm{~h}$ before the cells were seeded. After cells were cultured for $24 \mathrm{~h}$, flow cytometric analysis was performed. 


\section{Determination and selection of tip cells}

For determining the percentage of tip cells, cells were harvested using TrypLE (Gibco), fixed in 4\% paraformaldehyde in PBS for $15 \mathrm{~min}$ at room temp, and incubated with anti-CD34-phycoerythrin antibody (diluted 1:50; anti-CD34-PE; clone QBend-10, Thermo Scientific) for $30 \mathrm{~min}$ at room temperature. Cells were analyzed flow cytometrically using a FACSCalibur (Becton Dickinson, Franklin Lakes, NJ, USA) and FlowJo 6.4.7 software (Tree Star, San Carlos, CA, USA). The FITC channel was used to detect autofluorescence. Non-stained and nontreated cells were used as negative controls. For cell sorting experiments, cells were sorted on the basis of CD34 expression as detected with anti-CD34-PE on a Sony SH800z cell sorter (Sony Biotechnology, Surrey, UK). CD34- cells were cultured for 6 or $24 \mathrm{~h}$, and then cells were fixed, stained, and analyzed using flow cytometry as described above.

\section{Apoptosis}

Cellular apoptosis was assessed by measuring binding of annexin-V conjugated with FITC, following manufacturer's instructions (Molecular Probes, catalog number: V13242, Eugene, OR, USA) in combination with staining for CD34 to determine apoptosis in tip cells and non-tip cells.

\section{RNA isolation and quantitative PCR}

Total RNA was isolated from cells using the TRIzol method according to the manufacturer's instructions (Invitrogen, Carlsbad, CA, USA). An amount of $1 \mu \mathrm{g}$ RNA was used for DNase I treatment (amplification grade; Invitrogen) and reverse transcribed into cDNA using the Maxima First Strand cDNA Synthesis Kit (Thermo Scientific). Real-time quantitative PCR (RT qPCR) was performed using a CFX96 real-time PCR detection system (Bio-Rad Laboratories, Hercules, CA, USA) as described previously [6]. Primer details are presented in Supplementary Table 1. NCBI BLAST confirmed the specificity of the primers. The presence of a single PCR product was verified by both the presence of a single melting temperature peak and detection of a single band of the expected size on agarose gels. Non-template controls were included to verify the method and the specificity of the primers. PCR products that did not show a single melting temperature peak were excluded from analysis. $\mathrm{Ct}$ values were converted to arbitrary absolute amounts $\left(2^{-C t} \times 1 \mathrm{E}^{12}\right)$ and expressed as fold change as compared to controls. Expression data were normalized to tyrosine 3-monooxygenase/tryptophan 5-monooxygenase activation protein zeta (YWHAZ) mRNA levels.

\section{siRNA knockdown}

HUVECs and hMVECs were transfected with $25 \mathrm{nM}$ of either a non-targeting small interfering RNA (siNT) or a gene-specific siRNA and $2.5 \mu \mathrm{g} / \mathrm{mL}$ DharmaFECT 1 transfection agent (Dharmacon, Lafayette, CO, USA). The cells were transfected for $6 \mathrm{~h}$ using the reversed transfection method according to the manufacturer's instructions. Transfection efficiency was checked at the mRNA level and was considered acceptable when expression was reduced by at least $70 \%$ after $72 \mathrm{~h}$.

\section{Spheroid-based sprouting assay}

Spheroid experiments were performed with siRNA-transfected cells or cells that were sorted on the basis of CD34 expression. HUVECs transfected with siRNA were harvested after $48 \mathrm{~h}$, and 750 cells per spheroid were seeded in methylcellulose (Sigma-Aldrich, Buchs, Switzerland) containing M199 medium and 2\% human serum to allow spheroid formation [17, 18]. Cells sorted according to CD34 expression were immediately seeded in the same manner. After $18 \mathrm{~h}$, the spheroids were embedded in collagen gels containing $0.5 \%$ human serum and, when indicated, treated with VEGF-A ( $25 \mathrm{ng} / \mathrm{mL})$ or IGF2 $(50 \mathrm{ng} / \mathrm{mL})$, and were allowed to sprout for $24 \mathrm{~h}$. Images were taken using a phasecontrast microscope and the number of sprouts and average sprout length per spheroid were analyzed using the Neuron-J plug-inn package of Image-J software [19]. Spheroid experiments were performed with HUVECs, since hMVECs did not sprout in this experimental setup.

\section{Statistics and data correction}

To correct for differences between donors, data from flow cytometry and spheroid experiments were corrected using the Factor Correction program as described previously [20]. Statistical analysis was performed using a Student's $t$ tests.

\section{Chicken chorioallantoic membrane (CAM) assay}

The anti-angiogenic efficacy of a custom siIGF2 (Dharmacon) was tested in the CAM model $[18,21]$ via topical administration (each time $25 \mu \mathrm{l}$ ), between embryo development day (EDD) 7 and 8 once daily. Control eggs (blank) received $25 \mu \mathrm{l}$ of HEPES (4-(2-hydroxyethyl)-1-piperazineethanesulfonic acid) buffer (Gibco) or $25 \mu$ of non-targeting control siRNA (siNT) (SR-C2000-005; Eurogentec, Liege, Belgium) premixed with HEPES buffer and transfection reagent (DharmaFECT-1; Dharmacon). At EDD 9, the 
in ovo CAMs were visualized by means of FITC-dextran (20 kDa, $25 \mathrm{mg} / \mathrm{mL}$; Sigma-Aldrich) epi-fluorescence angiography [22] and subsequently analyzed by an image-processing quantification method as described previously [23]. Briefly, on the basis of FITC-dextran fluorescence angiography, the skeleton overlay of the vascular network was placed on top of the vascular network, and branching points $/ \mathrm{mm}^{2}$ were calculated.

\section{Zebrafish Morpholino experiments}

Zebrafish experiments were performed with the approval of the Animal Ethics Committee of the University of Amsterdam and in compliance with the Association for Research in Vision and Ophthalmology (ARVO) statement for the Use of Animals in Ophthalmic and Vision Research. $T g$ (Flila:eGFP) transgenic zebrafish embryos were injected with Morpholino oligonucleotides against IGF2a or IGF2b that were designed and tested previously $[15,24]$. For each gene, a 6-bp mismatch control was used, and a p53 Morpholino as a control for non-specific activation by Morpholino injection. After 24 and $30 \mathrm{~h}$, the chorion was manually removed and zebrafish were mounted in $0.5 \%$ agarose gels and analyzed using confocal microscopy. Details of Morpholino sequences are shown in Supplementary Table 1.

\section{Results}

\section{Human microvascular endothelial cell cultures contain $\mathrm{CD} 4^{+}$tip cells}

We have previously identified CD34 as a marker for tip cells in monolayer cultures of HUVECs [6], which are of macrovascular origin. hMVECs are primary cells of microvascular origin, and derived from the endothelial cell types which generate new vessels in vivo, and may therefore be physiologically more relevant for studies of angiogenesis. To study whether tip cells are also present in monolayer cultures of hMVECs, we analyzed CD34 expression with flow cytometry and confocal microscopy, using anti-CD34 antibodies. This revealed a subpopulation of CD $34^{+}$hMVECs with filopodia-like extensions (Fig. 1a) of approximately 10\% (Fig. 1b).

Freshly isolated HUVECs and hMVECs express CD34 on all cells $[25,26]$, but the percentage of $\mathrm{CD} 34^{+}$cells gradually tapers with increasing passage numbers until an equilibrium has been reached which is maintained for several passages. In HUVEC cultures, the equilibrium is reached at passage 3 , whereas in hMVEC cultures the equilibrium is reached at passage 9 . We examined whether CD34 expression in hMVECs either marks newly generated tip cells or identifies cells that have retained their phenotype
Fig. 1 Human microvascular endothelial cell cultures contain $\mathrm{CD} 34^{+}$tip cells. a Identification of tip cells by staining with antiCD34 (green), F-actin (phalloidin, red), and nuclei (DAPI, blue) in hMVECs. Representative examples are shown. Arrowheads indicate filopodia-like extrusions on $\mathrm{CD} 4^{+}$cells. Scale bar represents $25 \mu \mathrm{m}$ (first 3 images) and $100 \mu \mathrm{m}$ (last image). b HMVECs were analyzed for CD34 expression using flow cytometry. c-e Re-expression of CD34 in hMVECs after cell sorting. CD34- cells (shown in c) were cultured and CD34 expression was analyzed after $6 \mathrm{~h}(\mathbf{d})$ and $24 \mathrm{~h}$ (e). f, $\mathbf{g}$ The effect of exposure to VEGF or bFGF (f) and DLL4 (g) on the percentage of $\mathrm{CD} 34^{+}$tip cells. BSA was used as a control for DLL4. ${ }^{*} p<0.05$ as compared to control. Data are shown as the mean \pm standard deviation after factor correction $(n=3)$. h Fold change in mRNA expression levels of known tip cell genes in CD34 ${ }^{+}$ hMVECs as compared to CD34- hMVECs. Graph shows fold change of expression in $\mathrm{CD} 34^{+}$cells as compared to $\mathrm{CD} 34^{-}$cells after factor correction $(n=5) . * p<0.05, * * p<0.01, * * * p<0.001$

since isolation. For this purpose, we sorted and cultured CD $34^{-}$hMVECs and found that between 6 and $24 \mathrm{~h}$ after the $\mathrm{CD} 34^{-}$cells were plated a new fraction of $\mathrm{CD} 34^{+}$cells appeared (Fig. 1c-e). This suggests that $\mathrm{CD} 34^{+}$cells develop de novo in CD34- hMVEC cultures.

Next, we determined whether VEGF, DLL4, and bFGF changes tip cell differentiation, as measured by the percentage of tip cells in hMVECs, in a similar manner as was reported for tip cells in vivo. In the developing mouse retina, VEGF stimulates tip cell formation [1], whereas DLL4 inhibits the tip cell phenotype $[27,28]$ and bFGF induces proliferation of blood vessels [29]. In hMVEC cultures, VEGF significantly increased the percentage of $\mathrm{CD} 34^{+}$ cells (Fig. 1f). In contrast, DLL4 and bFGF significantly decreased the percentage of $\mathrm{CD} 34^{+}$cells (Fig. 1f, g).

Analysis of mRNA expression of genes that have been associated with a tip cell phenotype in the developing mouse retina and zebrafish embryos [1, 4, 5, 30-38] showed that 13 out of the 14 genes have significantly higher expression levels in CD34+ ${ }^{+}$than in CD34- hMVECs (Fig. 1h).

These experiments show that CD $34^{+} \mathrm{hMVECs}$ are phenotypically and genotypically similar to tip cells in vivo.

\section{Knockdown of ANGPT2 expression inhibits tip cell differentiation and sprouting}

As a further validation of our in vitro tip cell model, we investigated whether knockdown of the expression of known tip cell genes affects the percentage of tip cells in a similar way as was reported in vivo. For this purpose, we selected ANGPT2 and TIE1. Knockdown of Angpt2 was reported to reduce the number of tip cells at the retinal sprouting front in the developing mouse retina $[11,39]$ and knockdown of the orphan receptor Tiel in mouse retinas resulted in stalk cell apoptosis [12]. Previously published microarray data (Geo Accession: GSE 34850) showed that ANGPT2 and TIE1 mRNA levels were significantly higher in $\mathrm{CD} 34^{+}$HUVECs 

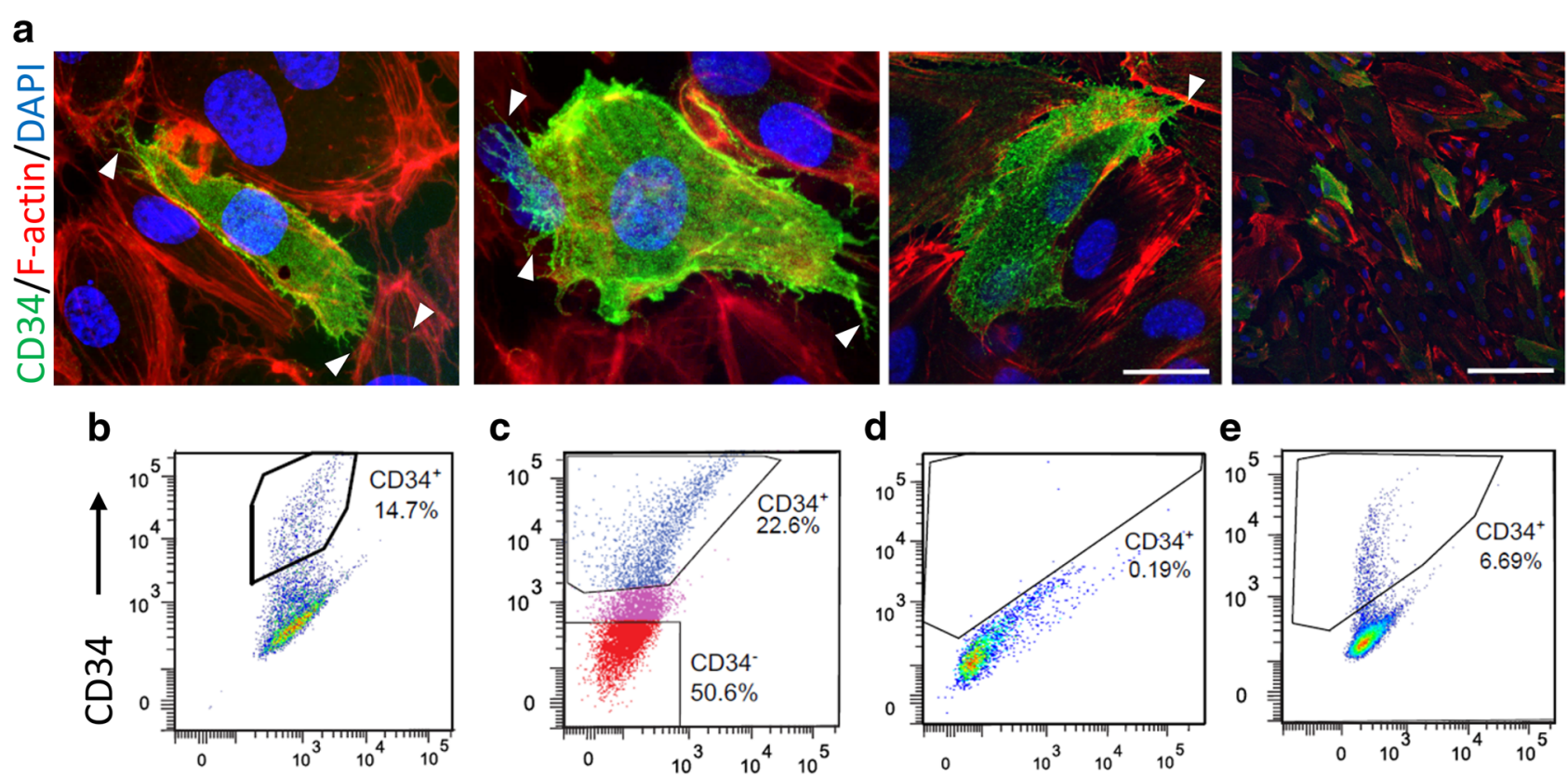

C

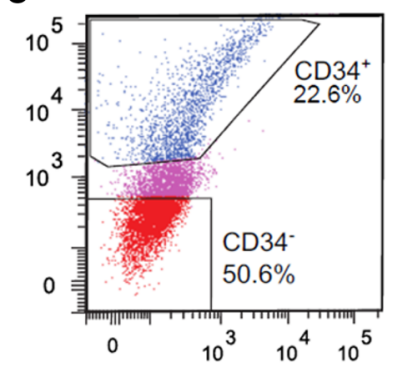

d

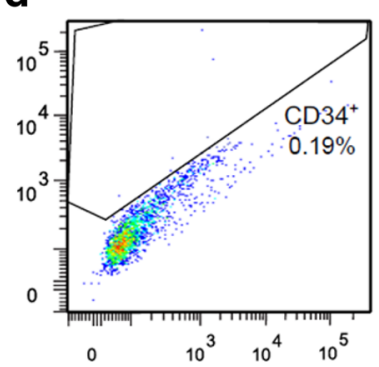

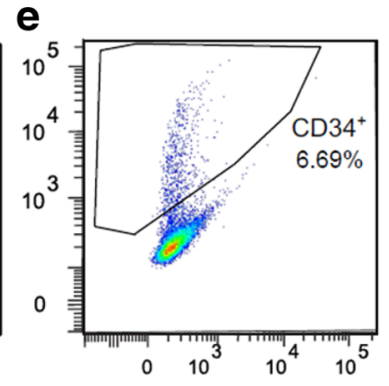

Autofluorescence
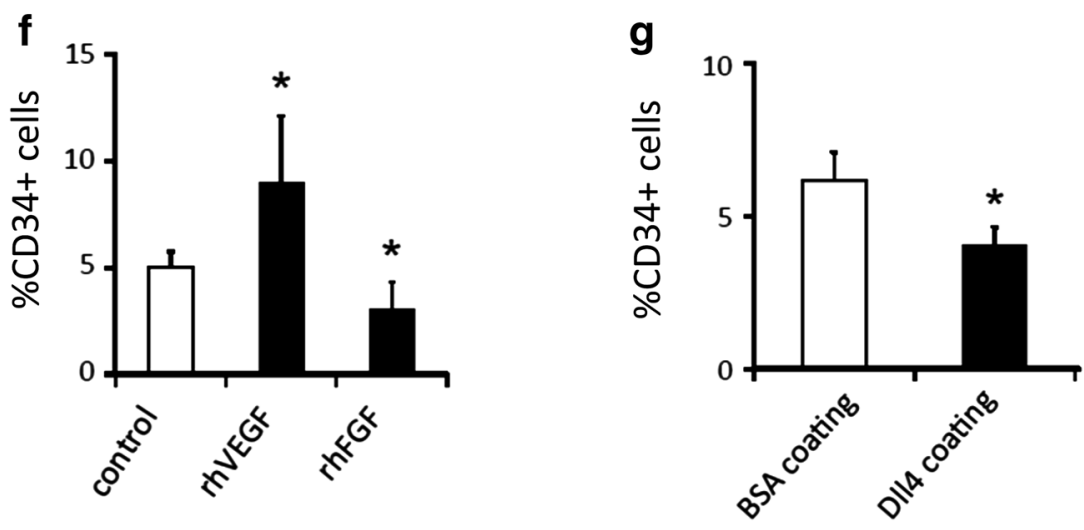

h

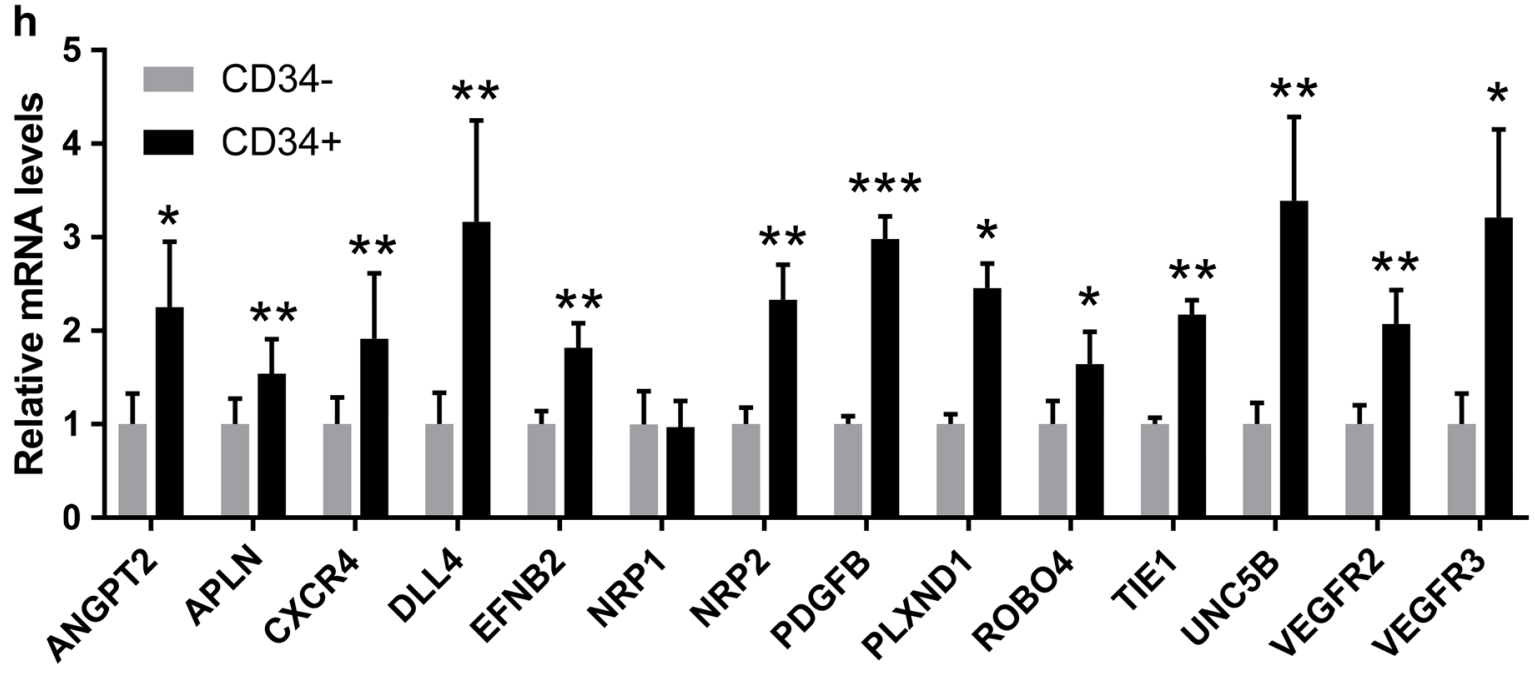



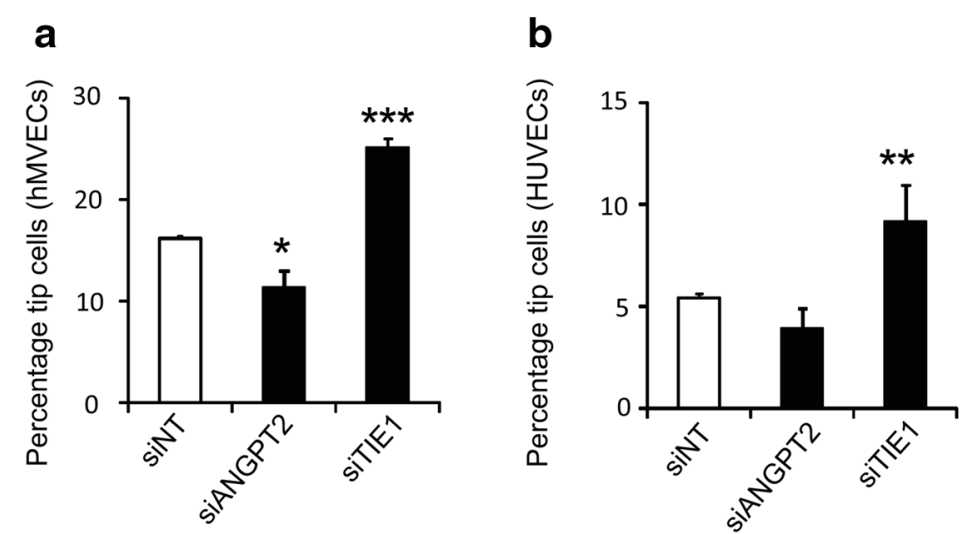

\section{C}

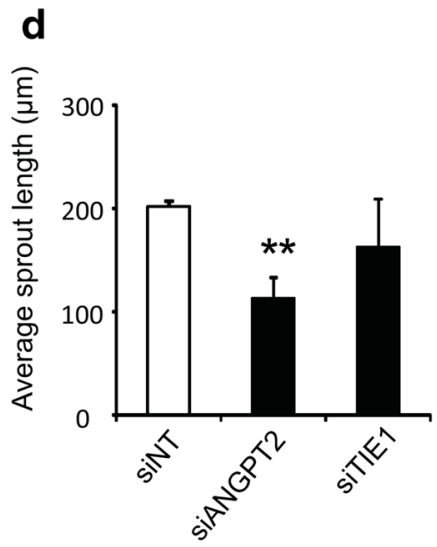

e
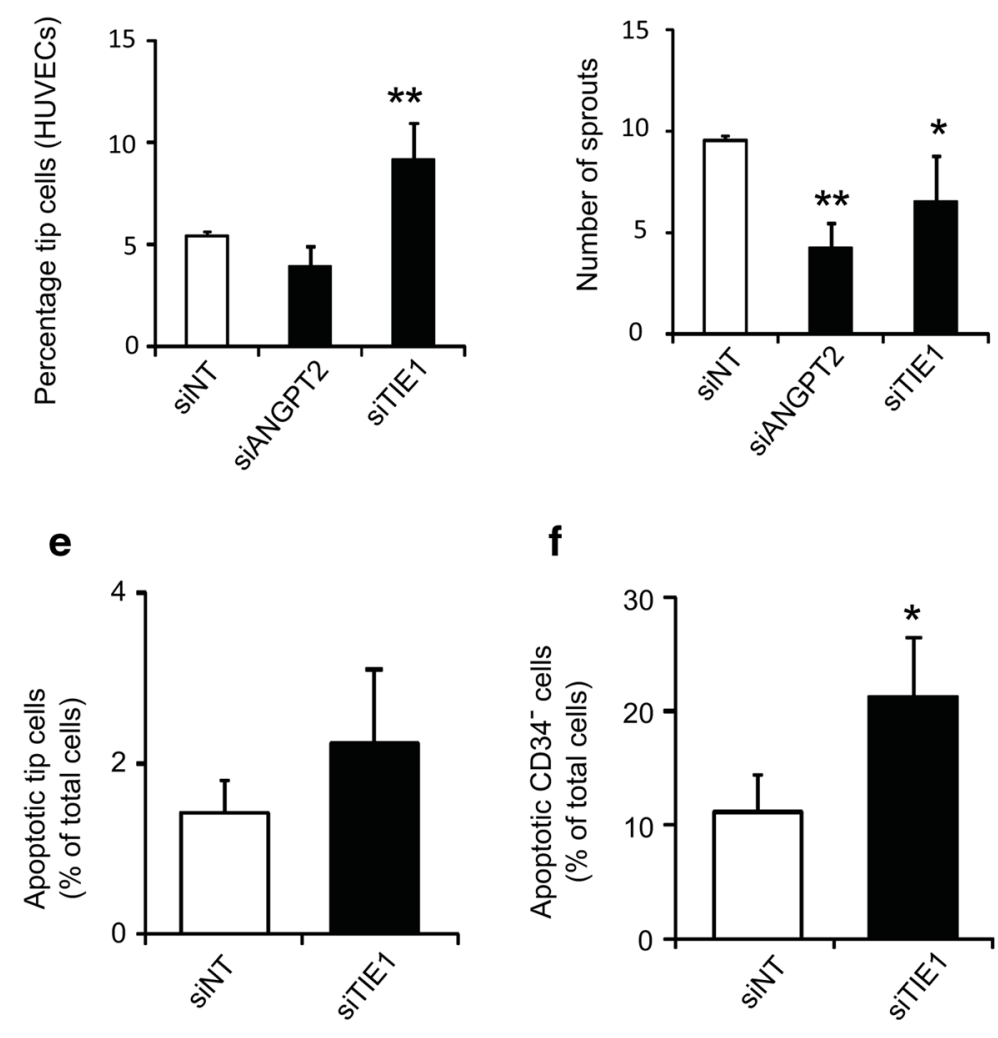

f

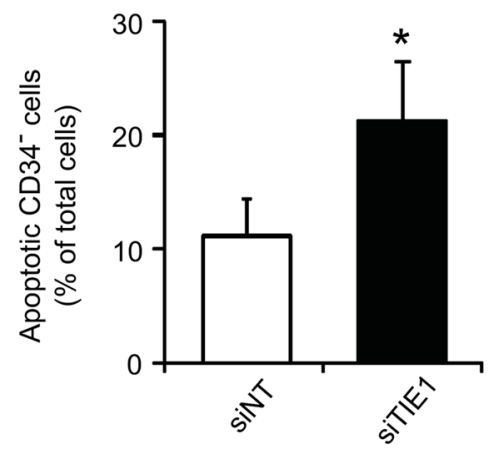

g

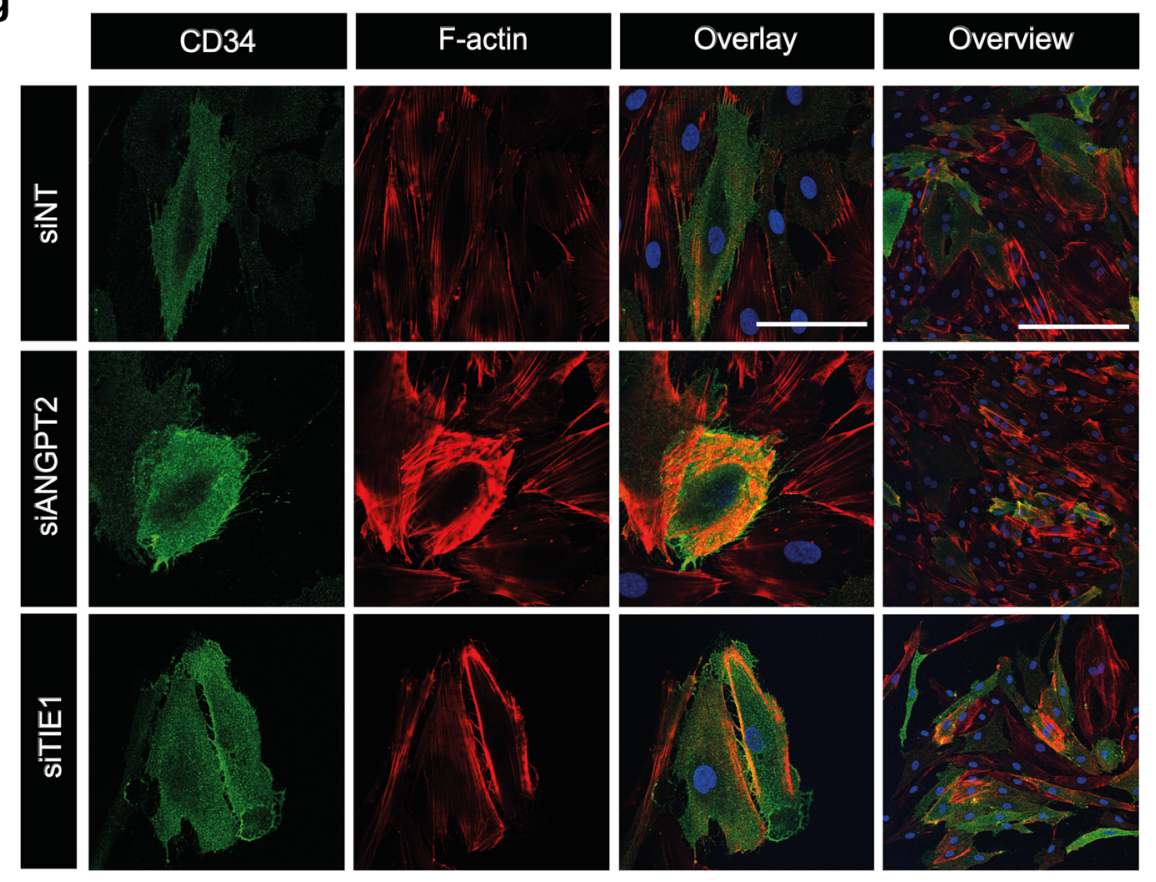


4 Fig. 2 Effects of ANGPT2 and TIE1 knockdown on $\mathrm{CD}_{3} 4^{+}$tip cells and $\mathrm{CD} 34^{-}$non-tip cells in vitro. a, b Effect of knockdown of ANGPT2 and TIE1 expression on percentages of $\mathrm{CD}^{+} 4^{+}$tip cells. Bars show percentages of CD $34^{+}$hMVECs (a) and HUVECs (b) as detected by flow cytometry after treatment with non-targeting siRNA (siNT), siANGPT2, or siTIE1. c, d Quantification of numbers of sprouts (c) and average sprout length (d) of spheroids of HUVECs treated with siNT, siANGPT2, or siTIE1. e, f Percentages of apoptotic cells as detected by flow cytometry after treatment of HUVECs with siNT or siTIE1. Staining for CD34 was performed in combination with annexin-V staining of apoptotic CD34 ${ }^{+}$tip cells (e) and CD34cells (f). Data in a-f are shown as mean \pm standard deviation after factor correction. ${ }^{*} p<0.05, * * p<0.01, * * * p<0.001$ as compared to siNT $(n=3)$. g Analysis of CD34 ${ }^{+}$tip cell morphology after knockdown of ANGPT2 and TIE1 expression. Staining of CD34 (green), F-actin (phalloidin, red), and nuclei (DAPI, blue) in hMVECs and overlay images of higher and lower magnification. Note the cortical F-actin staining in the cells treated with siANGPT2. Scale bars represent $50 \mu \mathrm{m}$ (first 3 columns) and $100 \mu \mathrm{m}$ (last column)

than in CD34- cells [6], which was confirmed for hMVECs by qPCR as well (Fig. 1h).

Knockdown of $A N G P T 2$ expression by siRNA reduced the percentages of $\mathrm{CD} 34^{+}$tip cells significantly in hMVECs (Fig. 2a), but not in HUVECs (Fig. 2b). However, in the HUVEC spheroid-based sprouting model, sprout numbers and average sprout length were significantly decreased after knockdown of ANGPT2 expression (Fig. 2c, d), and resulted in a disturbance of the actin cytoskeleton, as the number of short radial stress fiber-like actin bundles was increased (Fig. 2g).

Knockdown of TIE 1 expression resulted in a significant increase in the $\mathrm{CD}_{3} 4^{+}$tip cell fraction in HUVECs (1.7fold; Fig. 2a) and HMVECs (1.6-fold; Fig. 2b). The number of sprouts in the HUVEC spheroid model was marginally decreased (Fig. 2c), whereas sprout length was unaffected (Fig. 2d). Immunocytochemical staining of CD34 and F-actin showed that knockdown of TIE1 expression did not result in morphological changes in HUVECs (Fig. 2g). After TIE1 knockdown, apoptosis in CD34- cells was higher (22.3\%) than in siNT-treated HUVECs $(11.1 \%)$, whereas the percentage of apoptotic tip cells was much lower (1.4\%) with no difference as compared to siNT control (Fig. 2e, f). This indicates that at least part of the measured increase in tip cell percentage after TIEI knockdown was due to apoptosis of the $\mathrm{CD} 34^{-}$non-tip cells.

Together, we show that by using our in vitro tip cell model, we were able to reproduce observations reported on tip cells after ANGPT2 and TIE1 knockdown in vivo.

\section{Expression of IGF2 and IGF1R are essential for tip cell maintenance}

Our microarray data of HUVECs showed that mRNA expression levels of IGF2 were 45 -fold higher in CD34 ${ }^{+}$ cells as compared to $\mathrm{CD} 34^{-}$cells [6]. In addition, expression levels of IGFIR, a receptor for IGF2, were 2.1-fold higher in $\mathrm{CD} 34^{+}$cells [6]. IGF2 is known to stimulate angiogenesis in vitro, and increased IGF2 mRNA expression was found in vascular tufts in the retina of mice in the oxygen-induced retinopathy model [40] and in human vascular tumors such as hemangiomas [13, 40, 41]. To investigate whether IGF2 is specifically involved in tip cell fate, we performed knockdown of IGF2 and IGFIR expression in hMVECs and HUVECs, which resulted in decreased percentages of $\mathrm{CD} 34^{+}$tip cells (Fig. 3a, b) and reduced numbers of sprouts per spheroid (Fig. 3c). Knockdown of expression of $I G F 2$ but not of $I G F 1 R$ reduced sprout length (Fig. 3d). Knockdown of $I G F I R$ expression increased the intensity of F-actin staining in hMVECs in all cells. Knockdown of $I G F 2$ seemed to increase the intensity of F-actin staining in all cells as well, but most strongly in $\mathrm{CD} 34^{+}$cells (Fig. 3e).

To investigate the effects of exogenous IGF2 on the percentage of tip cells and sprouting, we exposed HUVECs to IGF2 $(50 \mathrm{ng} / \mathrm{ml})$ in both models. Addition of IGF2 did not alter the $\mathrm{CD} 34^{+}$fraction in HUVEC cultures (Fig. 3f), but did increase the number of sprouts per spheroid (Fig. 3g, h). Next, we determined the effects of IGF2 on sprouting from spheroids composed of sorted CD34- cells, CD $34^{+}$ cells, and unsorted human microvascular endothelial cells (HMEC-1s). We used the immortalized cell line HMEC-1 for these experiments, as the timespan before appearance of de novo-generated CD34 ${ }^{+}$tip cells in $\mathrm{CD} 34^{-}$cultures is over $72 \mathrm{~h}$ in HMEC-1 cells, but only $24 \mathrm{~h}$ in hMVECs and HUVECs. Lack of expression of CD34 protein was confirmed by immunocytochemistry on HMEC-1 spheroids after completion of the experiment (data not shown). Similarly to spheroids of unsorted cells, in spheroids of CD34 ${ }^{+}$ cells the number of sprouts was increased by VEGF and IGF2. In contrast, spheroids composed of CD34- cells had less sprouts per spheroid and did not respond to VEGF or IGF2 (Fig. 3h, i). We performed an apoptosis assay to determine whether the effects observed on tip cell percentages and sprouting were caused by apoptosis (Supplementary Fig. 1). Treatment with siIGF2 resulted in higher $(p<0.05)$ percentages of apoptotic cells in the tip cell $(10 \%)$ and CD34- cell (19\%) fractions, respectively, as compared to siNT (5 and $8 \%$, respectively). Treatment of HUVECs with siIGF1R did not alter the percentage of apoptotic cells as compared to siNT.

To further investigate the role of IGF2 in angiogenesis, we knocked down IGF2 expression in vivo, using the developing CAM model in chicken embryos [23] and zebrafish embryos, respectively. In the CAM model, silencing of $I G F 2$ resulted in a twofold reduction in number of vascular branching points per $\mathrm{mm}^{2}$ (Fig. $4 \mathrm{a}, \mathrm{b}$ ), in larger avascular areas in between vessels, and in irregular vascular caliber (Fig. 4b). Gene silencing of the two zebrafish IGF2 isoforms (IGF2A and IGF2B) using Morpholinos in zebrafish 

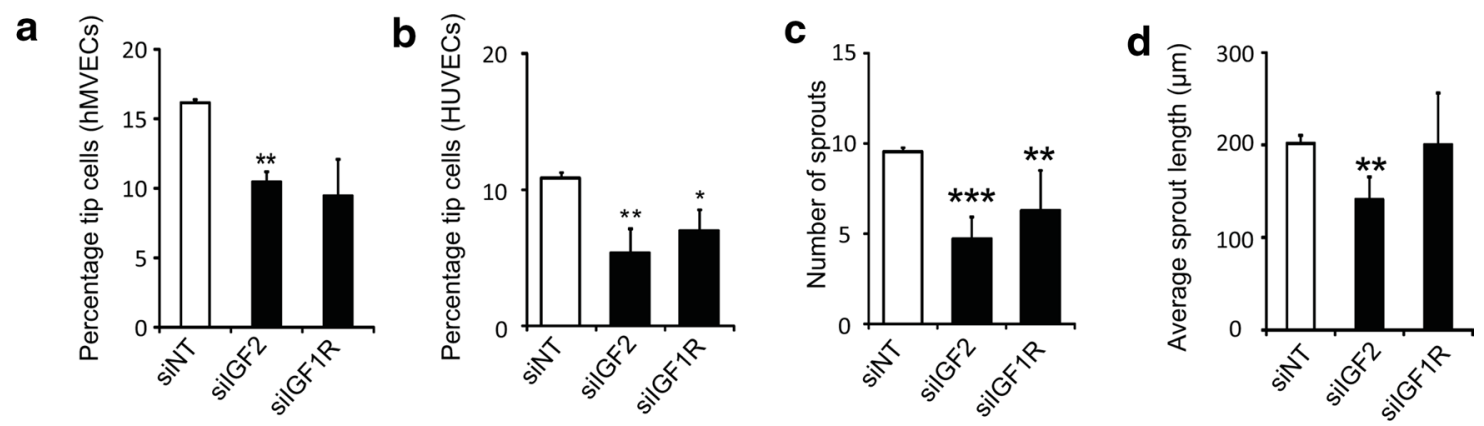

e
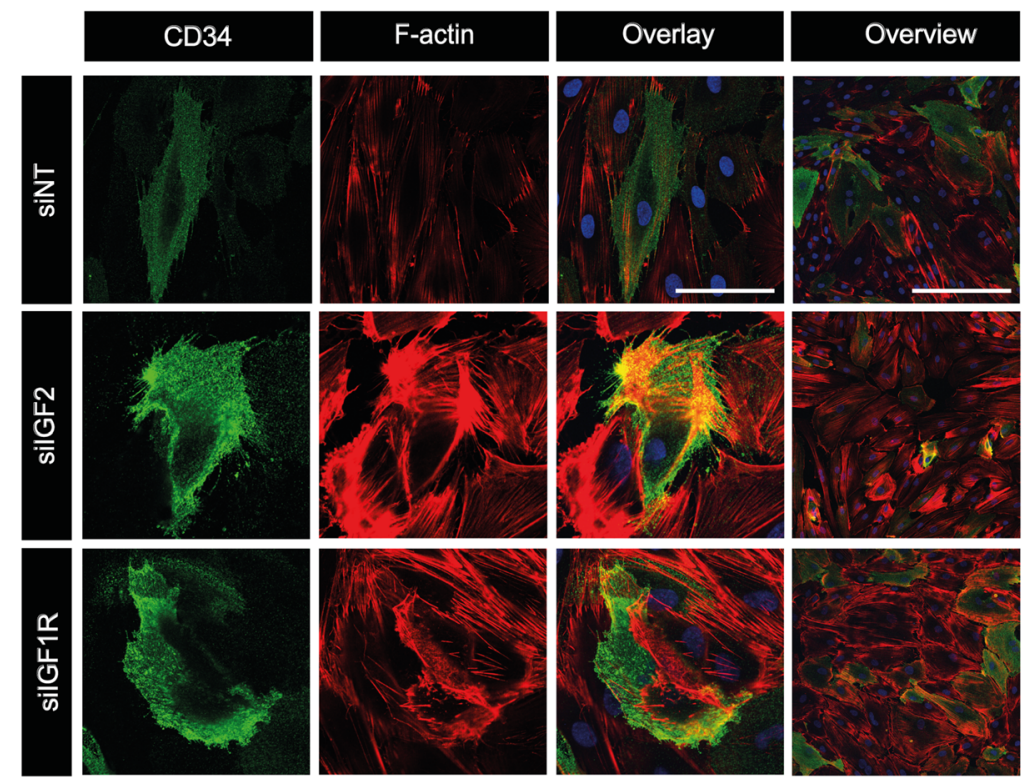

f

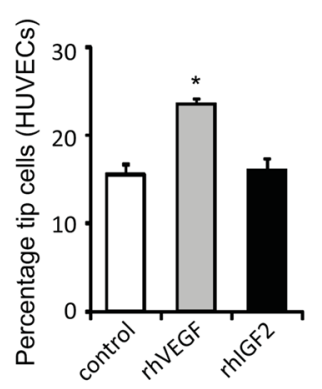

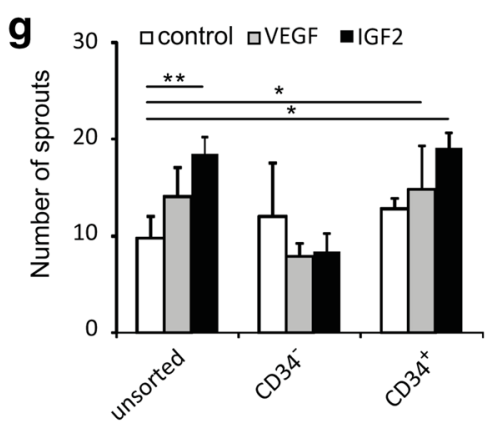

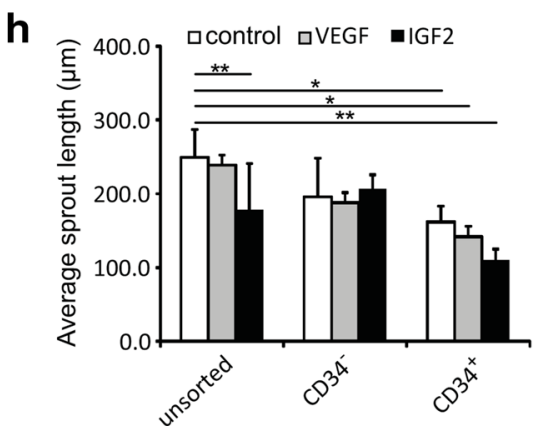

Fig. 3 IGF2 and IGF1R are essential for $\mathrm{CD} 4^{+}$tip cell fate. a, b Effect of knockdown of $I G F 2$ and IGFIR expression on percentages of $\mathrm{CD} 34^{+}$tip cells. Bars show percentages of CD34 ${ }^{+}$hMVECs (a) and HUVECs (b) treated with siNT, siIGF2, or siIGF1R as detected by flow cytometry. c, d Quantification of numbers of sprouts (c) and average sprout length (d) of spheroids composed of HUVECs after treatment with siNT, siIGF2, or siIGF1R. e Analysis of CD $34^{+}$tip cell morphology after knockdown of IGF2 and IGFIR expression. Staining of CD34 (green), F-actin (phalloidin, red), and nuclei (DAPI, blue) in hMVECs. Scale bars represent $50 \mu \mathrm{m}$ (first 3 col- umns) and $100 \mu \mathrm{m}$ (last column). f Effect of rhIGF2 on CD34 ${ }^{+}$ HUVEC tip cell percentages. Bars shows $\mathrm{CD} 34^{+}$tip cells of HUVECs treated with either $25 \mathrm{ng} / \mathrm{mL}$ BSA, $25 \mathrm{ng} / \mathrm{mL}$ VEGF-A, or $50 \mathrm{ng} / \mathrm{mL}$ rhIGF2 as detected by flow cytometry. $\mathbf{g}$, $\mathbf{h}$ Effects of VEGF and IGF2 on the number of sprouts (g) and average sprout length (h) in spheroids of CD34+ tip cells or CD34- non-tip cells. Data in $\mathbf{a}-\mathbf{d}$ and $\mathbf{f}-\mathbf{h}$ are shown as mean \pm standard deviation after factor correction. $* p<0.05, * * p<0.01, * * * p<0.001$ as compared to control

post-fertilization (Fig. 4c, d). Silencing of $I G F 2 B$ resulted in chaotic sprouting of ISVs after 24 and $30 \mathrm{~h}$ with some ISVs developing slower than their neighbors, and reduced numbers of filopodia (Fig. 4c, d). 


\section{Discussion}

In the present study, we show that primary microvascular endothelial cells, hMVECs, contain a subset of CD34 ${ }^{+}$ tip cells. This finding is similar to our earlier finding of CD34 ${ }^{+}$tip cells in macrovascular HUVEC cultures and immortalized endothelial cells such as HMEC-1 and RF24 [6], suggesting that the formation of tip cells in endothelial cell cultures is a general phenomenon. We found that knockdown of the expression of two known tip cell-specific genes, ANGPT2 and TIE1, had the same effects on tip cell fate in vitro as has been reported on the basis of in vivo studies. In addition, we identified IGF2 and IGF1R to be highly expressed in $\mathrm{CD} 34^{+}$tip cells and we showed that these molecules are essential for tip cell fate and function in vitro and for angiogenesis in vivo. Together, these results further contribute to the acceptance of our in vitro tip cell model as a valid model. The use of our model will help to gain insight into novel cellular and molecular mechanisms that are of importance in tip cell biology.

\section{CD34 identifies tip cells in hMVEC cultures}

CD34 is ubiquitously expressed on the luminal surface of endothelial cells of small blood vessels, but also has a striking presence on filopodia of tip cells in vivo [7, 42]. Although all endothelial cells express CD34 directly after isolation, after a certain number of passages CD34 expression is limited to a small fraction of cells, $[25,26]$ which we here identify as tip cells in vitro. Since CD34 expression re-appeared within $24 \mathrm{~h}$ in cultures of CD34- $\mathrm{hMVECs}$ that were sorted by FACS, we conclude that these cells are generated de novo in endothelial cell cultures. Immunocytochemistry showed that CD $34^{+} \mathrm{hMVECs}$ in vitro have filopodia-like extensions that are positive for CD34, similarly to the extensions of tip cells in sprouting vascular fronts in mouse retina and in human colon carcinoma in vivo $[1,8$, 43]. Stimulation of hMVECs with VEGF and DLL4 resulted in increased and decreased tip cell percentages, respectively, mimicking the regulatory effects on tip cells of these factors in vivo [1, 27, 28]. Finally, analysis of mRNA expression levels of genes known to be higher expressed in tip cells as compared to stalk cells in vivo demonstrated that these genes are also expressed at significantly higher levels in CD34 ${ }^{+}$ cells than in CD34- hMVECs.

Similar findings were previously demonstrated in our study of $\mathrm{CD} 34^{+}$cells in HUVECs [6]. In addition to the presently reported results in hMVECs, in HUVECs TNF $\alpha$ was shown to reduce the fraction of $\mathrm{CD} 34^{+}$tip cells, and $\mathrm{CD} 34^{+}$cells showed a higher capacity in cell migration and a much lower proliferation rate than $\mathrm{CD} 34^{-}$cells [6]. Genome-wide mRNA profiling analysis of $\mathrm{CD} 34^{+}$cells demonstrated enrichment for biological functions related to angiogenesis and migration, whereas $\mathrm{CD} 34^{-}$cells were enriched for functions related to proliferation. Furthermore, gene set enrichment analysis (GSEA) showed that our gene set and gene sets of other studies comprising the transcriptional profile of tip cells $[4,5,16]$ correlated strongly.

Taken together, we conclude that the $\mathrm{CD} 34^{+}$fraction in endothelial cell cultures can be used to study what molecular mechanisms determine the formation of the tip cell phenotype, their behavior, and their gene expression. However, careful evaluation of experimental results is required to ascertain whether the outcome is due to positive effects on the $\mathrm{CD} 34^{+}$fraction, or rather by negative effects on the CD34- $4^{-}$fraction, or by a direct effect on CD34 itself. We have taken this into account in our present experiments. For example, bFGF reduced the percentage of $\mathrm{CD} 34^{+}$tip cells in hMVECs. Since bFGF is reported to stimulate endothelial cell proliferation during angiogenesis $[29,44]$ and CD $34^{+}$ cells have a low proliferation rate, we interpreted the reduced percentage of $\mathrm{CD} 34^{+}$cells to be a result of increased proliferation of $\mathrm{CD}^{-} 4^{-}$cells, rather than of a direct downregulation of the numbers of $\mathrm{CD} 34^{+}$tip cells. However, the effect on cell proliferation should be further confirmed in experiments with FACS-sorted CD34 ${ }^{+}$and $\mathrm{CD} 34^{-}$cells exposed to bFGF. As another example, knockdown of TIEI increased the fraction of $\mathrm{CD} 34^{+}$cells. However, silencing of TIEI in developing mouse retinas causes increased apoptosis of stalk cells [12]. Similarly, in our study, knockdown of TIE1 in vitro caused increased apoptosis of CD34- but not of $\mathrm{CD} 34^{+}$cells. Therefore, we conclude that apoptosis of CD34- cells upon knockdown of TIE1 most likely contributes to or explains the observed increase in the fraction of $\mathrm{CD} 34^{+}$cells.

\section{Knockdown of ANGPT2 inhibits endothelial cell sprouting}

We studied the effects of ANGPT2 and TIE1 silencing on $\mathrm{CD} 34^{+}$tip cells to further validate our in vitro tip cell model as a tool to study genes enriched in tip cells, and to further study the role of these two genes in tip cell biology. Mice lacking ANGPT2 have decreased numbers of tip cells at the sprouting front in the developing retinal vasculature, and show severely impaired angiogenesis [11, 39]. ANGPT2 binds to integrins that interact with the actin cytoskeleton, and thus may play a role in regulating cell migration [11, 45]. Our experiments in vitro revealed decreased tip cell percentages and decreased sprouting from spheroids upon knockdown of $A N G P T 2$. Furthermore, the actin skeleton of cells treated with siANGPT2 was disturbed. Since tip cells and stalk cells can switch phenotype [3], and as it has been hypothesized that the best-equipped cells become tip cells $[3,46]$, we hypothesize that knockdown of ANGPT2 
a

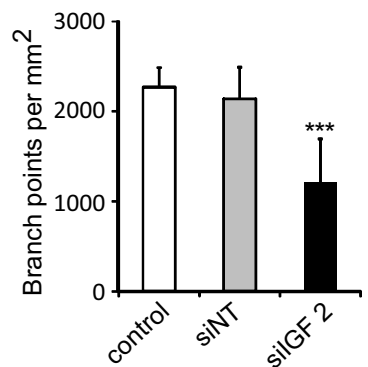

b
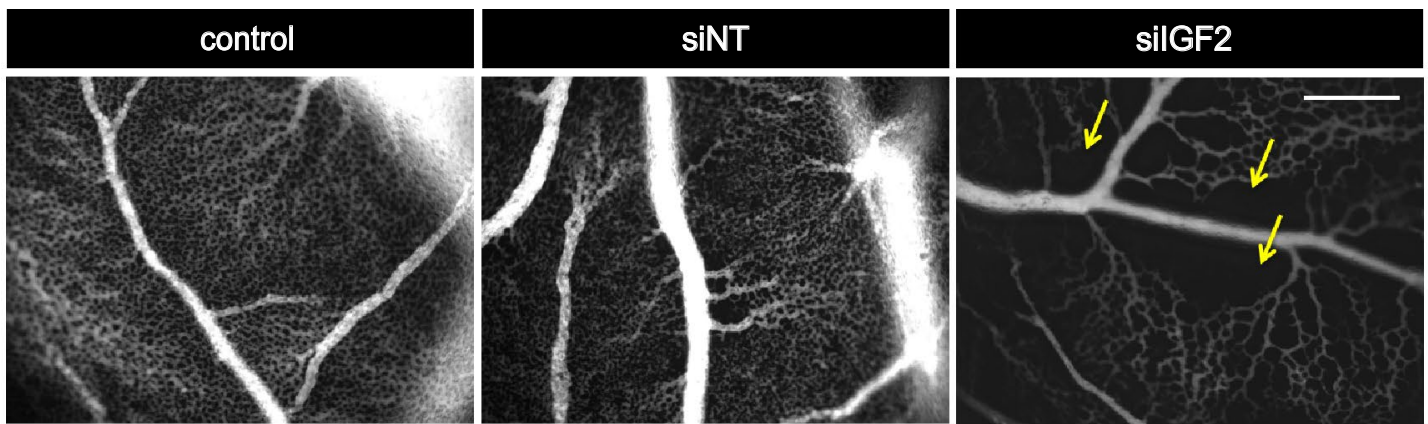

c
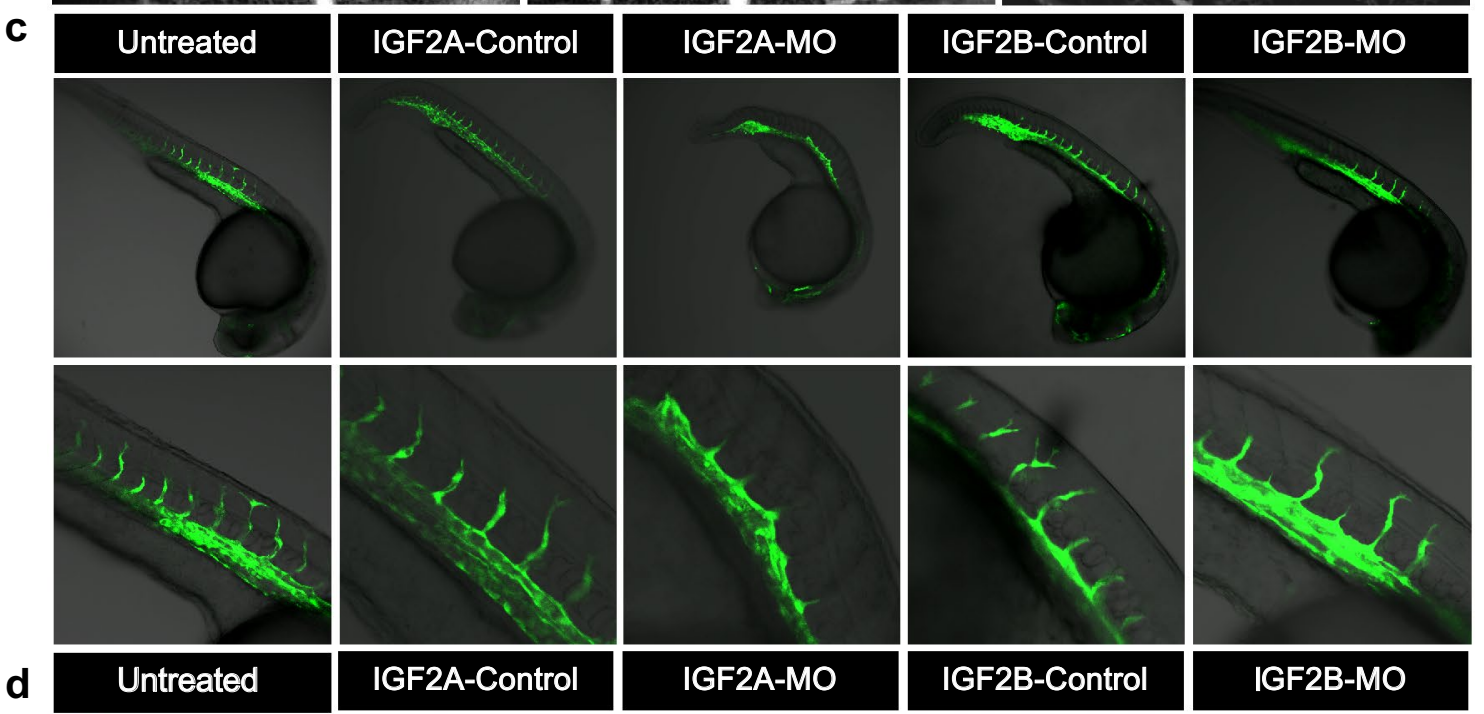

d
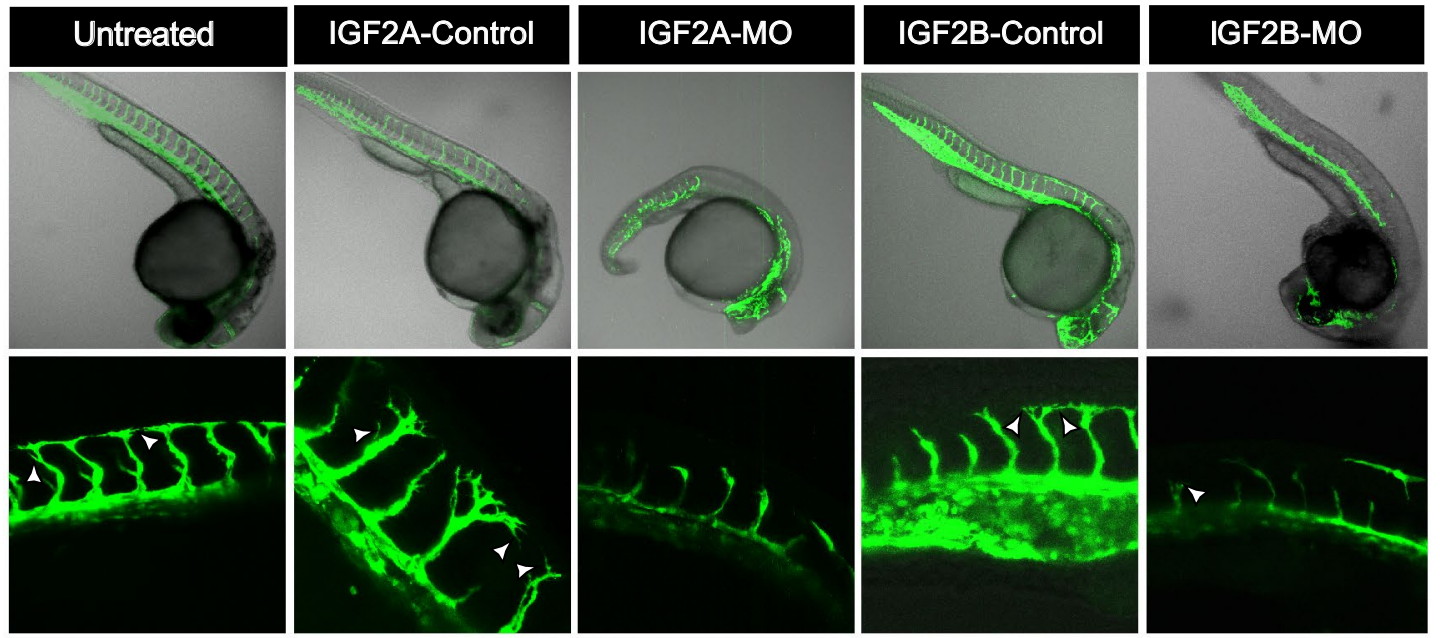

decreases migration of endothelial cells, which renders them unsuitable to become tip cells. Phenotype switching of neighboring non-tip cells requires migratory abilities to enable cells to reach the sprouting front [47]. Since neighboring cells also lack ANGPT2 and are thus impaired in their migratory abilities, these cells are unable to take over the tip 
4Fig. 4 IGF2 is essential for sprouting in the CAM model and zebrafish embryos. a Quantification of number of branching points/ $\mathrm{mm}^{2}$ comparing untreated membranes and membranes treated with siNT or with siIGF2 in the CAM model. $* * * p<0.001$ as compared to control as well as siNT treatment. b Representative images of the vascular network in CAMs of chicks that were treated with siNT or siIGF2 and untreated control. Arrows indicate non-vascularized areas in the vascular network. Scale bar represents $500 \mu \mathrm{m}$. c, d Representative images of $T g(f l i l a-e G F P)$ zebrafish embryos at $24 \mathrm{~h}$ (c) and $30 \mathrm{~h}$ (d) after injection of either a Morpholino targeting Igf $2 a$ (IGF2A-MO) or Igf $2 b$ (IGF2B-MO) or a 6-bp mismatch control Morpholino for each gene (IGF2A-CON and IGF2B-CON, respectively). Untreated zebrafish embryos are shown as a control. Arrowheads indicate filopodia

cell phenotype, which causes the tip cell fraction to decrease and sprouting to be reduced.

\section{IGF2 and IGF1R are essential for tip cell fate}

We used our in vitro tip cell model as a tool to identify and characterize novel tip cell-specific genes. From our microarray data [6], that comprised more than 400 differentially expressed genes, we selected $I G F 2$, a gene with one of the highest differences in mRNA levels in $\mathrm{CD} 34^{+}$cells as compared to $\mathrm{CD} 34^{-}$cells, and one of its receptors, IGFIR, which is also significantly higher expressed in $\mathrm{CD} 34^{+}$cells. On the basis of previous studies of knockdown of IGF2 and $I G F 1 R$ expression, it appeared that both proteins are important for angiogenesis in vivo and in vitro. This importance is reflected by reduced neovascularization in oxygen-deprived retinas, reduced mRNA expression in growing vascular tufts in developing mouse retinas, impaired angiogenesis in zebrafish embryos, and reduced sprouting in in vitro models of angiogenesis upon knockdown of $I G F 2$ and $I G F I R$ [13-15]. Downstream pathways of IGF2 and IGF1R include pathways that are important for tip cells, such as phosphatidylinositol 3-kinases (PI3K), a kinase that promotes cell migration [48-50]. However, a specific role in tip cells has not yet been reported for either protein. We show here that IGF2 is essential for maintenance of the tip cell phenotype, as knockdown of IGF2 expression reduced the percentage of CD34 $4^{+}$tip cells, which could not be explained by tip cellspecific apoptosis, since the percentages of apoptotic cells were higher in $\mathrm{CD}_{4} 4^{-}$cells than in $\mathrm{CD} 34^{+}$tip cells (19 and $10 \%$, respectively). IGF2 was also shown to be essential for angiogenesis, since knockdown of IGF2 expression reduced the number and length of sprouts in the spheroid assay. The role of IGF2 in angiogenesis was further supported by our in vivo experiments in the CAM assay and zebrafish, which show that sprouting in the absence of $I G F 2$ mRNA is chaotic and irregular.

Our experiments using spheroids composed of sorted $\mathrm{CD} 34^{+}$cells, CD34- cells, or mixed populations of cells show that stimulation with IGF2 increased the number of sprouts in $\mathrm{CD} 34^{+}$spheroids and in spheroids composed of mixed populations, but not in $\mathrm{CD} 34^{-}$spheroids. This suggests that IGF2 mainly acts on tip cells, which is confirmed by the staining for F-actin: disturbances in the actin skeleton upon knockdown of $I G F 2$ occurred mainly in tip cells. On the other hand, stimulation with exogenous IGF2 did not increase the fraction of tip cells cultured in monolayers, suggesting that the effects on sprouting of exogenous IGF2 may be dependent on other growth factors present in the gel in which the spheroids grow. Thus, our results suggest that that IGF2 alone does not induce de novo tip cell formation, but that endogenous IGF2 is necessary to maintain the tip cell phenotype, probably in an autocrine fashion.

IGF1R binds all ligands of the IGF family of growth factors: IGF1, IGF2, and insulin (INS) [51]. IGF1 and INS also play a role in angiogenesis, as has been shown in vivo and in vitro [52-55]. In the present study, we showed that tip cell percentages and sprouting are reduced upon knockdown of $I G F 1 R$, and that the actin skeleton is disturbed in all cells. This further supports the essence of the IGF family of growth factors, including IGF2, in tip cell formation and sprouting angiogenesis. We will further explore the underlying molecular mechanisms in future experiments.

\section{Conclusions}

In addition to the identification of tip cells in HUVECs, HMEC-1 cells, and RF24 cells, CD34 marks tip cells in cultures of hMVECs. This suggests that the existence of tip cells in endothelial cell cultures is a general phenomenon. Studying CD $34^{+}$tip cells in vitro can improve our understanding of tip cell biology by identifying proteins that are essential for tip cells, as was shown for ANGPT2 and TIE1. Finally, we provide evidence that IGF2 and IGF1R are novel tip cell proteins, and show that they are essential for maintenance of the tip cell phenotype.

Acknowledgements HMVECs were kindly provided by Dr. P. Koolwijk of the Department of Physiology (VU University Medical Center, Amsterdam). Advice for the zebrafish phenotyping was kindly provided by Prof. Dr. S. Schulte-Merker. Microscopy and flow cytometry experiments were performed at the core facility Cellular Imaging, Department of Cell Biology and Histology of the Academic Medical Centre, Amsterdam, The Netherlands. The authors were supported by the following foundations: MGD, BYA, RPK, IMCV, CJFvN, IK, ROS: Landelijke Stichting voor Blinden en Slechtzienden, Algemene Nederlandse Vereniging Ter Voorkoming Van Bindheid, Stichting Blindenpenning, Novartisfonds, and the ODAS stichting, that contributed through UitZicht (Grant UitZicht 2013-12). Other grants were provided by Rotterdamse Stichting Blindenbelangen (Grant B20130006), and Stichting Nederlands Oogheelkundig Onderzoek (Grant 2013-04). AWG, PNS: The authors acknowledge the funding from European Research Council (StG-2015-680209 to PNS), and the Dutch Cancer Society (VU2014-7234 to AWG and PNS). 
Author contributions MGD designed and performed experiments, analyzed data, and wrote the manuscript. IK, AG, PNS, and ROS designed experiments. BYA, RPK, IMCV, and PNS performed the experiments. BYA, ROS, CJFvN, and IK contributed to the discussion and editing of the manuscript. All authors have read and approved the final manuscript.

Funding The funding organizations had no role in the design or conduct of this research. They provided unrestricted grants.

Open Access This article is distributed under the terms of the Creative Commons Attribution 4.0 International License (http://creativeco mmons.org/licenses/by/4.0/), which permits unrestricted use, distribution, and reproduction in any medium, provided you give appropriate credit to the original author(s) and the source, provide a link to the Creative Commons license, and indicate if changes were made.

\section{References}

1. Gerhardt H, Golding M, Fruttiger M, Ruhrberg C, Lundkvist A, Abramsson A, Jeltsch M, Mitchell C, Alitalo K, Shima D, Betsholtz C (2003) VEGF guides angiogenic sprouting utilizing endothelial tip cell filopodia. J Cell Biol 161:1163-1177. https:// doi.org/10.1083/jcb.200302047

2. Siemerink MJ, Klaassen I, Van Noorden CJ, Schlingemann RO (2013) Endothelial tip cells in ocular angiogenesis: potential target for anti-angiogenesis therapy. J Histochem Cytochem 61:101-115. https://doi.org/10.1369/0022155412467635

3. Jakobsson L, Franco CA, Bentley K, Collins RT, Ponsioen B, Aspalter IM, Rosewell I, Busse M, Thurston G, Medvinsky A, Schulte-Merker S, Gerhardt H (2010) Endothelial cells dynamically compete for the tip cell position during angiogenic sprouting. Nat Cell Biol 12:943-953. https://doi.org/10.1038/ncb2103

4. del Toro R, Prahst C, Mathivet T, Siegfried G, Kaminker JS, Larrivee B, Breant C, Duarte A, Takakura N, Fukamizu A, Penninger J, Eichmann A (2010) Identification and functional analysis of endothelial tip cell-enriched genes. Blood 116:40254033. https://doi.org/10.1182/blood-2010-02-270819

5. Strasser GA, Kaminker JS, Tessier-Lavigne M (2010) Microarray analysis of retinal endothelial tip cells identifies CXCR4 as a mediator of tip cell morphology and branching. Blood 115:5102-5110. https://doi.org/10.1182/blood-2009-07-230284

6. Siemerink MJ, Klaassen I, Vogels IM, Griffioen AW, Van Noorden CJ, Schlingemann RO (2012) CD34 marks angiogenic tip cells in human vascular endothelial cell cultures. Angiogenesis 15:151-163. https://doi.org/10.1007/s10456-011-9251-z

7. Fina L, Molgaard HV, Robertson D, Bradley NJ, Monaghan P, Delia D, Sutherland DR, Baker MA, Greaves MF (1990) Expression of the CD34 gene in vascular endothelial cells. Blood 75:2417-2426

8. Schlingemann RO, Rietveld FJ, de Waal RM, Bradley NJ, Skene AI, Davies AJ, Greaves MF, Denekamp J, Ruiter DJ (1990) Leukocyte antigen CD34 is expressed by a subset of cultured endothelial cells and on endothelial abluminal microprocesses in the tumor stroma. Lab Invest 62:690-696

9. Clark ER, Clark EL (1939) Microscopic observations on the growth of blood capillaires in the living mammal. Dev Dyn 64:251-301

10. Bezuidenhout L, Zilla P, Davies N (2009) Association of Ang-2 with integrin beta 2 controls Ang-2/PDGF-BB-dependent upregulation of human peripheral blood monocyte fibrinolysis. Inflammation 32:393-401. https://doi.org/10.1007/s1075 3-009-9148-9
11. Felcht M, Luck R, Schering A, Seidel P, Srivastava K, Hu J, Bartol A, Kienast Y, Vettel C, Loos EK, Kutschera S, Bartels S, Appak S, Besemfelder E, Terhardt D, Chavakis E, Wieland T, Klein C, Thomas M, Uemura A, Goerdt S, Augustin HG (2012) Angiopoietin-2 differentially regulates angiogenesis through TIE2 and integrin signaling. J Clin Invest 122:1991-2005. https://doi. org/10.1172/JCI58832

12. Savant S, La Porta S, Budnik A, Busch K, Hu J, Tisch N, Korn C, Valls AF, Benest AV, Terhardt D, Qu X, Adams RH, Baldwin HS, Ruiz de Almodovar C, Rodewald HR, Augustin HG (2015) The orphan receptor Tie1 controls angiogenesis and vascular remodeling by differentially regulating Tie 2 in tip and stalk cells. Cell Rep 12:1761-1773. https://doi.org/10.1016/j.celrep.2015.08.024

13. Kim KW, Bae SK, Lee OH, Bae MH, Lee MJ, Park BC (1998) Insulin-like growth factor II induced by hypoxia may contribute to angiogenesis of human hepatocellular carcinoma. Cancer Res $58: 348-351$

14. Kondo T, Vicent D, Suzuma K, Yanagisawa M, King GL, Holzenberger M, Kahn CR (2003) Knockout of insulin and IGF-1 receptors on vascular endothelial cells protects against retinal neovascularization. J Clin Invest 111:1835-1842. https://doi.org/10.1172/ jci200317455

15. Hartnett L, Glynn C, Nolan CM, Grealy M, Byrnes L (2010) Insulin-like growth factor-2 regulates early neural and cardiovascular system development in zebrafish embryos. Int J Dev Biol 54:573-583. https://doi.org/10.1387/ijdb.092922lh

16. Harrington LS, Sainson RC, Williams CK, Taylor JM, Shi W, Li JL, Harris AL (2008) Regulation of multiple angiogenic pathways by Dll4 and Notch in human umbilical vein endothelial cells. Microvasc Res 75:144-154. https://doi.org/10.1016/j. mvr.2007.06.006

17. Korff T, Augustin HG (1998) Integration of endothelial cells in multicellular spheroids prevents apoptosis and induces differentiation. J Cell Biol 143:1341-1352

18. Nowak-Sliwinska P, Alitalo K, Allen E et al (2018) Consensus guidelines for the use and interpretation of angiogenesis assays. Angiogenesis. https://doi.org/10.1007/s10456-018-9613-x

19. Chieco P, Jonker A, De Boer BA, Ruijter JM, Van Noorden CJ (2013) Image cytometry: protocols for $2 D$ and $3 D$ quantification in microscopic images. Prog Histochem Cytochem 47:211-333. https://doi.org/10.1016/j.proghi.2012.09.001

20. Ruijter JM, Thygesen HH, Schoneveld OJ, Das AT, Berkhout B, Lamers WH (2006) Factor correction as a tool to eliminate between-session variation in replicate experiments: application to molecular biology and retrovirology. Retrovirology $3: 2$. https ://doi.org/10.1186/1742-4690-3-2

21. Nowak-Sliwinska P, Segura T, Iruela-Arispe ML (2014) The chicken chorioallantoic membrane model in biology, medicine and bioengineering. Angiogenesis 17:779-804. https://doi. org/10.1007/s10456-014-9440-7

22. Weiss A, Ding X, van Beijnum JR, Wong I, Wong TJ, Berndsen RH, Dormond O, Dallinga M, Shen L, Schlingemann RO, Pili R, Ho CM, Dyson PJ, van den Bergh H, Griffioen AW, NowakSliwinska P (2015) Rapid optimization of drug combinations for the optimal angiostatic treatment of cancer. Angiogenesis 18:233244. https://doi.org/10.1007/s10456-015-9462-9

23. Nowak-Sliwinska $P$, van Beijnum JR, van Berkel M, van den Bergh H, Griffioen AW (2010) Vascular regrowth following photodynamic therapy in the chicken embryo chorioallantoic membrane. Angiogenesis 13:281-292. https://doi.org/10.1007/s1045 6-010-9185-x

24. White YA, Kyle JT, Wood AW (2009) Targeted gene knockdown in zebrafish reveals distinct intraembryonic functions for insulinlike growth factor II signaling. Endocrinology 150:4366-4375. https://doi.org/10.1210/en.2009-0356 
25. Delia D, Lampugnani MG, Resnati M, Dejana E, Aiello A, Fontanella E, Soligo D, Pierotti MA, Greaves MF (1993) CD34 expression is regulated reciprocally with adhesion molecules in vascular endothelial cells in vitro. Blood 81:1001-1008

26. Hellwig SMM, Damen CM, van Adrichem NPH, Blijham GH, Groenewegen G, Griffioen AW (1997) Endothelial CD34 is suppressed in human malignancies: role of angiogenic factors. Cancer Lett 120:203-211

27. Suchting S, Freitas C, le Noble F, Benedito R, Breant C, Duarte A, Eichmann A (2007) The Notch ligand Delta-like 4 negatively regulates endothelial tip cell formation and vessel branching. Proc Natl Acad Sci USA 104:3225-3230. https://doi.org/10.1073/ pnas.0611177104

28. Hellstrom M, Phng LK, Hofmann JJ, Wallgard E, Coultas L, Lindblom P, Alva J, Nilsson AK, Karlsson L, Gaiano N, Yoon K, Rossant J, Iruela-Arispe ML, Kalen M, Gerhardt H, Betsholtz C (2007) Dll4 signalling through Notch1 regulates formation of tip cells during angiogenesis. Nature 445:776-780. https://doi. org/10.1038/nature05571

29. Javerzat S, Auguste P, Bikfalvi A (2002) The role of fibroblast growth factors in vascular development. Trends Mol Med 8:483-489

30. Gerhardt H, Ruhrberg C, Abramsson A, Fujisawa H, Shima D, Betsholtz C (2004) Neuropilin-1 is required for endothelial tip cell guidance in the developing central nervous system. Dev Dyn 231:503-509. https://doi.org/10.1002/dvdy.20148

31. Sawamiphak S, Seidel S, Essmann CL, Wilkinson GA, Pitulescu ME, Acker T, Acker-Palmer A (2010) Ephrin-B2 regulates VEGFR2 function in developmental and tumour angiogenesis. Nature 465:487-491. https://doi.org/10.1038/nature08995

32. Tammela T, Zarkada G, Nurmi H, Jakobsson L, Heinolainen K, Tvorogov D, Zheng W, Franco CA, Murtomaki A, Aranda E, Miura N, Yla-Herttuala S, Fruttiger M, Makinen T, Eichmann A, Pollard JW, Gerhardt H, Alitalo K (2011) VEGFR-3 controls tip to stalk conversion at vessel fusion sites by reinforcing Notch signalling. Nat Cell Biol 13:1202-1213. https://doi.org/10.1038/ ncb2331

33. Wang Y, Nakayama M, Pitulescu ME, Schmidt TS, Bochenek ML, Sakakibara A, Adams S, Davy A, Deutsch U, Luthi U, Barberis A, Benjamin LE, Makinen T, Nobes CD, Adams RH (2010) EphrinB2 controls VEGF-induced angiogenesis and lymphangiogenesis. Nature 465:483-486. https://doi.org/10.1038/nature09002

34. Witmer AN, van Blijswijk BC, Dai J, Hofman P, Partanen TA, Vrensen GF, Schlingemann RO (2001) VEGFR-3 in adult angiogenesis. J Pathol 195:490-497. https://doi.org/10.1002/path.969

35. Witmer A (2003) Vascular endothelial growth factors and angiogenesis in eye disease. Prog Retin Eye Res 22:1-29. https://doi. org/10.1016/s1350-9462(02)00043-5

36. Lu X, Noble Fl, Yuan L, Jiang Q, Lafarge B, Sugiyama D, Breant C, Claes F, Smet FD, Thomas J-L, Autiero M, Carmeliet P, Tessier-Lavigne M, Eichmann A (2004) The netrin receptor UNC5B mediates guidance events controlling morphogenesis of the vascular system. Nature 432:179-186

37. Koch AW, Mathivet T, Larrivee B, Tong RK, Kowalski J, PibouinFragner L, Bouvree K, Stawicki S, Nicholes K, Rathore N, Scales SJ, Luis E, del Toro R, Freitas C, Breant C, Michaud A, Corvol P, Thomas JL, Wu Y, Peale F, Watts RJ, Tessier-Lavigne M, Bagri A, Eichmann A (2011) Robo4 maintains vessel integrity and inhibits angiogenesis by interacting with UNC5B. Dev Cell 20:33-46. https://doi.org/10.1016/j.devcel.2010.12.001

38. Martyn U, Schulte-Merker S (2004) Zebrafish neuropilins are differentially expressed and interact with vascular endothelial growth factor during embryonic vascular development. Dev Dyn 231:33-42. https://doi.org/10.1002/dvdy.20048
39. Maisonpierre PC (1997) Angiopoietin-2, a natural antagonist for Tie2 that disrupts in vivo angiogenesis. Science 277:55-60. https ://doi.org/10.1126/science.277.5322.55

40. Lofqvist C, Willett KL, Aspegren O, Smith AC, Aderman CM, Connor KM, Chen J, Hellstrom A, Smith LE (2009) Quantification and localization of the IGF/insulin system expression in retinal blood vessels and neurons during oxygen-induced retinopathy in mice. Invest Ophthalmol Vis Sci 50:1831-1837. https://doi. org/10.1167/iovs.08-2903

41. Ritter MR, Dorrell MI, Edmonds J, Friedlander SF, Friedlander M (2002) Insulin-like growth factor 2 and potential regulators of hemangioma growth and involution identified by large-scale expression analysis. Proc Natl Acad Sci USA 99:7455-7460. https ://doi.org/10.1073/pnas.102185799

42. Siemerink MJ, Hughes MR, Dallinga MG, Gora T, Cait J, Vogels IM, Yetin-Arik B, Van Noorden CJ, Klaassen I, McNagny KM, Schlingemann RO (2016) CD34 promotes pathological epi-retinal neovascularization in a mouse model of oxygen-induced retinopathy. PLoS ONE 11:e0157902. https://doi.org/10.1371/journ al.pone. 0157902

43. Phng LK, Stanchi F, Gerhardt H (2013) Filopodia are dispensable for endothelial tip cell guidance. Development 140:4031-4040. https://doi.org/10.1242/dev.097352

44. Schweigerer L, Neufeld G, Friedman J, Abraham JA, Fiddes JC, Gospodarowic D (1987) Capillary endothelial cells produce basic fibroblast growth factor, a mitogen that promotes their own growth. Nature 325:257-259

45. Carlson TR, Feng Y, Maisonpierre PC, Mrksich M, Morla AO (2001) Direct cell adhesion to the angiopoietins mediated by integrins. J Biol Chem 276:26516-26525. https://doi.org/10.1074/jbc. M100282200

46. De Bock K, Georgiadou M, Schoors S, Kuchnio A, Wong BW, Cantelmo AR, Quaegebeur A, Ghesquiere B, Cauwenberghs S, Eelen G, Phng LK, Betz I, Tembuyser B, Brepoels K, Welti J, Geudens I, Segura I, Cruys B, Bifari F, Decimo I, Blanco R, Wyns S, Vangindertael J, Rocha S, Collins RT, Munck S, Daelemans D, Imamura H, Devlieger R, Rider M, Van Veldhoven PP, Schuit F, Bartrons R, Hofkens J, Fraisl P, Telang S, Deberardinis RJ, Schoonjans L, Vinckier S, Chesney J, Gerhardt H, Dewerchin M, Carmeliet P (2013) Role of PFKFB3-driven glycolysis in vessel sprouting. Cell 154:651-663. https://doi.org/10.1016/j. cell.2013.06.037

47. Palm MM, Dallinga MG, van Dijk E, Klaassen I, Schlingemann RO, Merks RM (2016) Computational screening of tip and stalk cell behavior proposes a role for apelin signaling in sprout progression. PLoS ONE 11:e0159478. https://doi.org/10.1371/journ al.pone. 0159478

48. Riedemann J, Macaulay VM (2006) IGF1R signalling and its inhibition. Endocr Relat Cancer 13(Suppl 1):S33-S43. https:// doi.org/10.1677/erc.1.01280

49. Graupera M, Potente M (2013) Regulation of angiogenesis by PI3K signaling networks. Exp Cell Res 319:1348-1355. https:// doi.org/10.1016/j.yexcr.2013.02.021

50. Harris LK, Westwood M (2012) Biology and significance of signalling pathways activated by IGF-II. Growth Factors 30:1-12. https://doi.org/10.3109/08977194.2011.640325

51. Bach LA (2015) Endothelial cells and the IGF system. J Mol Endocrinol 54:R1-R13. https://doi.org/10.1530/JME-14-0215

52. Hellstrom A, Carlsson B, Niklasson A, Segnestam K, Boguszewski M, De La Cerda L, Savage M, Svensson E, Smith L, Weinberger D, Albertsson Wikland K, Laron Z (2002) IGF-1 is critical for normal vascularization of the human retina. J Clin Endocr Metab 87:3413-3416

53. Jacobo SM, Kazlauskas A (2015) Insulin-like growth factor 1 (IGF-1) stabilizes nascent blood vessels. J Biol Chem 290:63496360. https://doi.org/10.1074/jbc.M114.634154 
54. Nakao-Hayashi J, Ito H, Kanayasu T, Morita I, Murota S (1992) Stimulatory effects of insulin and insulin-like growth factor I on migration and tube formation by vascular endothelial cells. Atherosclerosis 92:141-149
55. Grant MB, Mames RN, Fitzgerald C, Ellis EA, Aboufriekha M, Guy J (1993) Insulin-like growth factor I acts as an angiogenic agent in rabbit cornea and retina: comparative studies with basic fibroblast growth factor. Diabetologia 36:282-291 